\title{
Real Wages Versus Nominal Wages in the Albanian Economy
}

\author{
Dr. Imelda Sejdini \\ Lecturer, Faculty of Economy \\ "Aleksander Xhuvani" University, Elbasan,Albania \\ Email: imelda.sejdin@@uniel.edu.al / imelda.sejdini@yahoo.com
}

Msc. Ina Sejdini

Specialist of Statistics, Standards and Curriculum

"Aleksander Xhuvani" University, Elbasan,Albania

Email: ina.sejdini@uniel.edu.al / ina_sejdini@live.com

Doi:10.5901/ajis.2014.v3n2p183

\begin{abstract}
Nominal wages and real wages differ depending on the place and country. They are affected by many factors such as purchasing power of money, additional benefits received, working hours, job security, nature of employment, future prospects, social view of the job and cost of training. Our analysis is focused on real and nominal wages and factors that have an impact on this wages, in the Albanian economy. In this paper, we are going to analyze the change of average monthly wage in the last ten years in Albania, the change of $\mathrm{CPI}$ during the same period of time and the real wage growth impact in the Albanian economy, according to administrative data gained from official sources of information. As the levels of the real wage and employment are determined by labor market equilibrium, our analyzes comes with some valuable conclusions about the importance of strong labor market policies of the Albanian government, in order to help the working force to reach a decent standard of living. Interesting implications are explored for economist and policy makers, in order to assess the impact of unadjusted remuneration in the Albanian economy.
\end{abstract}

Keywords: real wage, nominal wage, labor market policies

\section{Introduction}

In the analysis and forecasting of macroeconomic developments, the wages are of relevant importance. Real wages, as determiners of the purchasing power of an employee, take into consideration the inflation of that period when they are provided. They refer to wages in terms of the amount of goods and services that can be bought. This term is used in contrast to nominal wages. Real wages earned by a given worker can fall over time even if nominal wages increase (Keynes,J.M., 1936). Real wages importantly influence the demand for labor and for other factors of production. Recently, a growing literature (Artis, M., Kontelemis, Z., \& D. Osborn, 1995), has emphasized the importance of real, rather than nominal wage for understanding macroeconomic fluctuations. Recent developments of real wages provide information on the role that market signals are playing in the adjustment of labor markets. The rise in unemployment following large falls in output and the hike in price inflation has been associated with a substantial fall in real wages in Central and Eastern Europe. Considering the differences in these economies, we can say that the picture is not the same for all of these countries, including Albania. Trends in real average monthly wage reflect changes in average labor income (before taxes and transfers) and hence provide a clearer picture of variations in the purchasing power of wages (Bender, K. \& I.Theodossiou,1999). Considering the differences in these economic variables, it is difficult to compare levels across countries. But in our analyses it is possible to draw some meaningful conclusions about changes over time.

\section{Wage fluctuations in the region before and after crisis}

Changes in monthly average wages summarize innumerable changes at enterprise level and sectorial level, including not only changes in the hourly wage rate but also changes in the number of hours worked. In many countries the global economic crisis has led to shorter hours of work owing to reductions in the amount of overtime, an increase in timerelated underemployment, or an increase in the proportion of part-time relative to full-time employees, all of which 
negatively affect total monthly wages. A reduction in working hours, usually leads to proportional reductions in monthly wages (Bils, M. 1985).

Trends in real average wages vary across regions and countries. There are differences across countries in the way wages are estimated by national statistical offices. While the most developed economies carry out regular establishment surveys and specific surveys on the structure of earnings, other countries collect wage data through labor force surveys, and definitions of what is counted as a wage sometimes differ.

The main unit of measure used for wages is the monthly average wage expressed in real terms (i.e. adjusted for inflation), which has been identified as an ILO "decent work indicator" (ILO, 2012b) ${ }^{1}$. The purpose of thinking about wages or any other values in "real" terms is to be able to compare them to past values in a meaningful way.

According to ILO reports during the last ten years, after some years characterized from strong growth, from 2003 to mid-2007, the world economy slowed down in 2008 and resulted negative in 2009 (ILO, 2013). This has not generally been the case in emerging and developing economies, where growth has merely decelerated. There have also been considerable differences among countries within regions. Dynamic policy intervention contributed to a stronger than expected recovery in 2010, with anticipated world economic output rising by 4.8 per cent. In emerging and developing economies, growth was anticipated to increase from 2.5 per cent in 2009 to 7.1 per cent in 2010, in contrast to a recovery in advanced economies from -3.2 per cent in 2009 to 2.7 per cent in 2010.

In the Eastern European countries, the regional growth rate in average real wages fluctuated widely, from the double digit rate before crisis, to the hard landing of 2009. Although positive wage growth returned in 2010 and 2011, the rates were not as high as the rates before crisis. In these countries, the output expanded faster than employment and the labor productivity grew up in all the region. The trends in the two largest economies of the region, Russia and Ukraine influenced the whole regional picture (Ashenfelter, O. 2012). In these two countries, the wage growth slowed down in 2008 and turned negative in 2009. This was due to an increase of an involuntary underemployment in 2009, when people worked less hours than they could have liked to work. Other employees experienced frozen wages and cut of bonuses (Kulikov, G \& V. Blyzniuk, 2010).

If we refer to the post crisis period, during 2008-2011 in Albania, the real wage growth were lower than before crisis, in spite of positive labor productivity growth and the same phenomenon was noted in Serbia too. During this period, with the advice of IMF, Albania introduced a budgetary restriction on wage growth in the public sector. Furthermore, on the advice of the IMF the so-called "thirteenth month" wage in the public sector was abolished in Hungary, resulting in an eight per cent cut in the annual basic wage. Similar advice from the same international financial institution was given to Bosnia and Herzegovina, Albania and the Former Yugoslav Republic of Macedonia. Meanwhile, in Serbia, there were further budgetary cuts and a significant reduction in the public sector wage bill in 2010, following the Government's commitment to the IMF to freeze public sector wages and pensions in nominal terms in 2009 and 2010.

Real wage growth declined by half on average during 2008-2009, while a certain number of countries even experienced real wage decline. In Central and Eastern Europe, real wage growth fell from 6.6 per cent in 2007 to 4.6 per cent in 2008 and -0.1 per cent in 2009 (ILO, 2010a). In general, real wages at first started to grow less strongly and then even began to fall. Other countries succeeded in maintaining a positive real wage growth in 2009, even if at a slower rate than in 2008, as for example in the Former Yugoslav Republic of Macedonia. In the Former Yugoslav Republic of Macedonia national statistics on the evolution of the average wage may not reflect the real situation due to a methodological change in the official collection of data, which saw an artificial increase of the average wages in 2008 following the integration of previous allowances in the basic wage. Real wages were found to have declined in 2009, even though real wages over the two-year crisis period had remained slightly positive. By contrast, real wage growth continued in 2009 in Bulgaria and Bosnia and Herzegovina but then started to slow down in both countries in 2010 due to the later arrival of the crisis. At the enterprise level, severe wage cuts even in nominal terms were reported in Albania and the Former Yugoslav Republic of Macedonia, where in 2009 several enterprises applied a provision of some branch collective agreements to reduce nominal wages by 20 per cent.

In general, the economic situation in the region has led to less generous wage increases in all sectors, after 2010. In some cases this may be due to reduced working hours following the economic slowdown. Lower nominal wage increases have been somewhat offset by the slowing down of inflation so that the fall in real wages has so far been less severe than might have been the case if they had been accompanied by high price increases.

${ }^{1}$ An alternative measure of wages would have been hourly wages, but these are available for only a limited number of countries with more advanced statistical systems. 


\section{The change of $\mathrm{CPI}$ and average monthly wage in nominal and real terms in Albania}

Wage policies affect the buying power of employees and the growing tendency of wages is a good indicator in improving their quality of life. Real wages are an important component of wealth. They constitute the main source of income for many households, especially for the less well-off. The behavior of real wages therefore has a direct bearing on income distribution and the level of poverty. What we note in the economy, is a decline of real wages during high inflation, and this relies on backward-looking indexation. If inflation accelerates, the adjustment of nominal wages lags behind and real wages fall (Dunlop, J.T., 1938). If we refer to inflation and average monthly wages in the last ten years in the Albanian economy, what we note is a positive growth rate although in decreasing percentage recently, according to official data published by INSTAT.

Beginning from the year 2004, the annual change of average nominal monthly wage was $14.4 \%$, the average annual change of CPI was $2.9 \%$ and the calculated real wage growth was $11.5 \%$. In 2005 , relative to the previous year 2004 , the average nominal monthly wage growth was $9.9 \%$ while consumer prices increased by $2.4 \%$, bringing growth in real wages by $7.5 \%$ (INSTAT, 2005). After two years, in 2007 the average nominal monthly wage growth was $17.1 \%$ while consumer prices increased by $2.9 \%$, bringing growth in real wages by $14.2 \%$. In 2008 , real wage growth has been lower, at $6.1 \%$ and this is due to average nominal wage growth of $8.3 \%$ and consumer price change of $2.2 \%$. In 2009 the average monthly nominal wage increased by $11.9 \%$ and consumer prices increased by $3.5 \%$, figures that led to real wage growth of $8.4 \%$. While in 2010, from different sources of information, the figures have shown that the increase in the average nominal monthly wage was about $6.7 \%$ and consumer prices increased by $3.6 \%$, which led to real wage growth by $3.1 \%$. In the last three years, we note: a real wage growth by $3.5 \%$ for the year 2011 as a result of average nominal monthly wage growth by $6.9 \%$ and consumer price index increase by $3.4 \%$; a real wage growth by $5.4 \%$ for the year 2012 as a result of average nominal monthly wage growth by 7,3\% and consumer price index increase by 1.9\%; a real wage growth by $2,0 \%$ as a result of average nominal monthly wage growth by $4,1 \%$ and consumer price index increase by $2,1 \%$ in the last year of our survey, in 2013. These calculations rely on official administrative data as shown in table 1.

Table 1. Average monthly wage changes in the public sector in real terms, 2004-2013

\begin{tabular}{|l|c|c|c|c|c|c|c|c|c|c|}
\hline Description & 2004 & 2005 & 2006 & 2007 & 2008 & 2009 & 2010 & 2011 & 2012 & 2013 \\
\hline Annual change of average monthly wage in public sector (\%) & 14.4 & 9.9 & 7.5 & 17.1 & 8.3 & 11.9 & 6.7 & 6.9 & 7.3 & 4.1 \\
\hline Average annual change of CPI (\%) & 2.9 & 2.4 & 2.4 & 2.9 & 2.2 & 3.5 & 3.6 & 3.4 & 1.9 & 2.1 \\
\hline Annual real wage growth (\%) & 11.5 & 7.5 & 5.1 & 14.2 & 6.1 & 8.4 & 3.1 & 3.5 & 5.4 & 2 \\
\hline
\end{tabular}

Source: Administrative data, INSTAT, BOA, 2014

The annual change of average monthly wage in the public sector has been positive, but this nominal wage growth, considering the inflation through average annual change of $\mathrm{CPI}$, has led to a lower real wage growth, although in positive figures.

As, is shown above, we have access only on data for the public sector and the lack of data for the private sector during the last four years of this period is a limitation of this study. In the table below, we show some data on average monthly wage per employee by economic activities, from 2003 to 2012, and these data include both, the public and private sector. These statistics provide an opportunity to compare salaries in different industries and different occupation groups (INSTAT, 2013).

Table 2. Average monthly wage per employee by economic activities, 2003-2012 (Albanian Leks)

\begin{tabular}{|l|c|c|c|c|c|c|c|c|c|c|}
\hline Economic Activity & $\mathbf{2 0 0 3}$ & $\mathbf{2 0 0 4}$ & $\mathbf{2 0 0 5}$ & $\mathbf{2 0 0 6}$ & $\mathbf{2 0 0 7}$ & $\mathbf{2 0 0 8}$ & $\mathbf{2 0 0 9}$ & $\mathbf{2 0 1 0}$ & $\mathbf{2 0 1 1}$ & $\mathbf{2 0 1 2}$ \\
\hline Industry & 18,286 & 19,200 & 20,200 & 21,950 & 24,735 & 32,214 & 32,837 & 33,273 & 35,746 & 36,994 \\
\hline Construction & 15,017 & 16,055 & 17,361 & 19,184 & 32,085 & 42,424 & 42,706 & 37,652 & 35,458 & 35,820 \\
\hline $\begin{array}{l}\text { Transport and } \\
\text { communication }\end{array}$ & 27,030 & 27,439 & 28,144 & 31,360 & 36,518 & 38,106 & 47,709 & 52,263 & 55,476 & 54,382 \\
\hline Trade & 14,120 & 15,711 & 17,561 & 20,677 & 27,301 & 32,217 & 34,959 & 31,179 & 32,962 & 33,705 \\
\hline Services & 18,159 & 17,574 & 18,517 & 19,869 & 23,636 & 28,073 & 30,197 & 28,819 & 31,819 & 34,165 \\
\hline Total & $\mathbf{1 8 , 5 2 2}$ & $\mathbf{1 9 , 0 3 9}$ & $\mathbf{1 9 , 9 9 3}$ & $\mathbf{2 1 , 8 4 2}$ & $\mathbf{2 7 , 3 5 0}$ & $\mathbf{3 4 , 2 7 7}$ & $\mathbf{3 6 , 0 7 5}$ & $\mathbf{3 4 , 7 6 7}$ & $\mathbf{3 6 , 4 8 2}$ & $\mathbf{3 7 , 3 0 5}$ \\
\hline
\end{tabular}

Source: Annual Business Structural Survey, 2000-2013 
If we do our own calculation relying on these figures, we can come with some conclusions that are not real because of lots of other activities not included in the table above. So we will take as a reference the data on public sector as real figures. Real growth of wages is of particular importance for the monitoring of economic indicators used by policy-makers, employers and unions to assess the conditions of demand and supply for labor.

\section{The impact of wage growth in the Albanian economy}

The focus of the Albanian government for maintaining the macroeconomic stability and achieving a sustainable economic growth, among other indicators are the tax system reformations. Stimulating business incentives and reducing the income tax from employment at $10 \%$ until the end of 2013 , accompanied by reduction of social contributions and other reforms coming with the change of fiscal policy, have contributed in the positive growth of annual real wage during the last ten years in Albania. By decision of the council of Ministers, starting from 1 May 2013, the wages up to All 30 thousand shall be excluded from the Personal income Tax liability (Official Journal of Albania, 2013) ${ }^{2}$. This decision might have encouraged businesses to declare a higher number of employees.

During the first year after crisis, in 2009 the wages in Albania increased by about $8.4 \%$ in real terms. This was attributed to the public sector increases while in the private sector the wages remained almost unchanged. According to the Bank of Albania, the private sector responded to the global crisis by freezing pay rises for its employees. The public sector on the other hand benefited from an increase in wages in May 2009, a month before the general elections in Albania. The national wage in the public and private sector is increased each year during the last years, according to the data published by INSTAT. In the industrial sector, the average wage during 2007 is increased by $13 \%$ relative to the previous year 2006 and $22 \%$ relative to the year 2005. In the construction sector, the wage during 2007 is increased by $67 \%$ relative to the previous year 2006 and $85 \%$ relative to the year 2005. In the transport and telecommunication sector, which are the sectors with the biggest average wage, the wage during 2007 is increased by $16 \%$ relative to the previous year 2006 and 30\% relative to the year 2005. In the trade sector, the wage during 2007 is increased by $32 \%$ relative to the previous year 2006 and $55 \%$ relative to the year 2005.

In the sector of services, the wage during 2007 is increased by $19 \%$ relative to the previous year 2006 and $28 \%$ higher, relative to the year 2005 . After a rose of about $14.2 \%$ percent in the last quarter of 2007 , the annual growth rate of wages slowed down for both public and private sector in the first three quarters of 2008. In nominal terms, in the private sector for the first nine months of 2008 rose by about $15,1 \%$. In real and annual terms, average wage in economic enterprises rose by about 11.0 percent for this period. Over the first three quarters of 2008, average annual nominal wage in the production sector rose by an average of $19,8 \%$ in construction and $11.8 \%$ in industry. In services, wholesale and retail trade posted a high average annual rise by 12,9 and 25,5 percent, respectively.

According to the labor market evaluations, the same rhythms are noted in the private sector too. The government has adopted some measures in order to save the competitive abilities of businesses, according partial compensation for the training costs and sequential compensation for the social insurance contributions for the companies that hire unemployed job seekers and especially for the fason businesses. The fiscal charge on business is highly reduced related to the profit tax reduction from $20 \%$ to $10 \%$ and the decrease of social insurance payment from $38.5 \%$ during 2006 to $24.5 \%$ from May 2009. The reduction is mainly related to the employer part of contribution, which is almost half decreased (from $29 \%$ to $15 \%$ ).

The cyclical economic weakness was reflected in the partial utilization of capacities in the capital and labor markets. (Deveraux, P.J., 2001) The labor market remained sluggish in the period under review. Unemployment rate remained unchanged from end 2012, settling at $12.8 \%$ in 2013. Government's fiscal measures introduced in May seem to have encouraged the declaration of employees, leading to increase in employment in the private non-agricultural sector in the first nine months of 2013. However, unemployment rate remained high and generated weak pressures for the raise in wages in the economy. In addition, the weak final demand restricted businesses' ability to dictate final product prices, resulting eventually in low profit margins. In the absence of unexpected supply-side shocks and in the presence of the anchored inflation expectations, the conditions of the real economy and the weak domestic demand, in particular, will keep inflation rates low in the period ahead (BOA, 2013).

During the last ten years, the public administration wage growth is above the annual inflation rates declared by

2 Official Journal no. 53, dated 15 April 2013, law no. 107/2013, dated 28.03.2013: On some amendments to the law no. 8438, dated 28.12.1998 "On income tax" amended. 
INSTAT. At the same time, the differentiated wage growth policies in different sectors like education, healthcare, public security, etc. has realized every year an annual wage growth higher than the annual price index (Ceni, A., 2013). So the average monthly wage of doctors increased by $84 \%$ during 2008 related to 2005 and $100 \%$ during 2009 , related to 2005.The average monthly wage of nurses increased by $89 \%$ during 2008 related to 2005 and $100 \%$ during 2009 , related to the same year 2005. According to business survey, wages in economy contracted in 2013 , marking higher contraction were those in hotels (by $8.2 \%$ in real annual terms) and trade (by $6.1 \%$ in real annual terms).

By contrast, in the production sectors, the decline in the value added and employment was associated with slight increase in the average wage on a year earlier (by $1.0 \%$ in real terms). After registering continuous fall in 2012, average wage index in the economy rose $4.6 \%$ in the beginning of 2013, as reported by the latest statistics. CPi-deflated, real wage recorded an annual increase of $2.1 \%$. The performance of wages was positively affected by the increase in wages in the production sector. On the other hand, wages in services continued the downtrend begun since end-2011. Real wage in the public sector rose $3.5 \%$ in annual terms.

The average monthly wage of educators increased by $75 \%$ during 2008 related to 2005 and $100 \%$ during 2009 , related to the same year 2005. This wage growth is due to two main reasons: first of all, these sectors were distinguished by low wages although the difficult work they do and secondly, considering them with priority in wage growth, the government has projected to fight the corruption.

In the continuous attempt to protect the low income people, the Albanian government has increased with significant rhythms the minimum wage. So during 2006, the minimum wage was increased by $18,6 \%$ and during 2008 was increased twice, by $6,2 \%$ and related to the same period of the previous year, the minimal wage was increased by $21,4 \%$, while before 2006 it was increased by 7-9\% (World Bank, 2008). From May 2009, the minimum wage was 5,9\% higher than during 2008 and $52,5 \%$ higher than during 2005. The last growth during July 2013 was by $4,8 \%$ related to the previous growth of July 2012, as shown in Table 3 .

Table 3. Official minimum wage in Albania, 2004-2013

\begin{tabular}{|c|c|c|c|c|c|c|c|c|c|c|}
\hline Description & 2004 & 2005 & 2006 & 2007 & 2008 & 2009 & 2010 & 2011 & 2012 & 2013 \\
\hline Official minimum wage (Leks) & 10,080 & 11,800 & 14,000 & 14,000 & 17,000 & 18,000 & 19,000 & 20,000 & 21,000 & 22,000 \\
\hline
\end{tabular}

\section{Source: INSTAT 2014}

To realize the wage policies, it is negotiated with employees and employers of both public and private sector in order to attain social consent, because the wage is an important factor for the economic activity encouragement and also an important factor for the poverty reduction (Fields, G.S., \& R. Kanbur, 2007). This process has been periodically realized in the moments of minimum wage revisions, wage indexation, etc. activating the Wages Commission of National Labor Council. The role of the National Labor Council, which was founded as an advisory body to the Government, has so far played only a minor role. Branch collective agreements are signed for specific sectors and apply to all employers and employees in those sectors as the minimum level for setting wages (World Bank, 2006). These are relevant mostly for the public sector where they define in more details the coefficients used to outline the basic price of labor for the specific post and category of worker. While wages in the public sector were increased, this was not the result of collective bargaining negotiations and followed a unilateral Government decision. Collective bargaining in the private sector is possible by law, but so far has been limited in practice

In the conditions of the world economic crisis and the influence transmitted in the economy of Albania, in the preliminary meetings done by employers and employees, organizations in order to decide for the minimum wage changes, used a lot of attention in order to save the business from economic damage, and especially the fason businesses (Fullani, 2010). In order to protect the employees from the wage discrimination, the state has approached the trade unions for including the minimum wage in all the collective bargains, as a factor of important priority, especially to the small - private enterprises, securing the employees for the minimum floor of their incomes.

The state has also the right to interfere by negotiating in all the divergences encountered from the way the employees are paid. The Albanian government, according to the fourth article of European Social Card, is trying to reach the parameters requested, by saving the share of $60 \%$ between minimal national wage and average national wage and this is another reason why we have continuous growth of the minimum wage. Actually this rapport is $42.18 \%$, although the considerable growth of the minimum wage and this is because of the influence in the average wage, the growth of wages in the education and healthcare sectors. Related to this, it is very important to note the positive influence of the 
wage growth in the productivity growth. Figures in table 4, show a positive change of GDP, before and after crisis, but the impact was lower after 2008, although in positive figures.

Table 4. Real annual change of GDP

\begin{tabular}{|c|c|c|c|c|c|c|c|c|c|c|}
\hline Period & $\mathbf{2 0 0 4}$ & $\mathbf{2 0 0 5}$ & $\mathbf{2 0 0 6}$ & $\mathbf{2 0 0 7}$ & $\mathbf{2 0 0 8}$ & $\mathbf{2 0 0 9}$ & $\mathbf{2 0 1 0}$ & $\mathbf{2 0 1 1}$ & $\mathbf{2 0 1 2}$ & $\mathbf{2 0 1 3}$ \\
\hline Real annual change of GDP (\%) & 5.7 & 5.7 & 5.4 & 5.9 & 7.5 & 3.3 & 3.8 & 3.1 & 1.3 & 0.7 \\
\hline
\end{tabular}

Source: World Economic Outlook, IMF(2014), INSTAT (2014)

In 2008, there were no significant indications of any direct or indirect threat to the financial system as a result of the international financial crisis, given the low international exposure of Albanian banks (BOA, 2010). Growth in 2008 was more than 6 per cent. Despite this sound economic framework, the impact of the global crisis started to be visible during the last quarter of 2008, and even more in early 2009. Based on official statistical data, as of January 2009 exports had decreased by 11 per cent compared to January 2008. The crisis was also becoming evident in construction which has experienced a decrease in turnover. In 2010 the volume of turnover in comparison with the fourth quarter of 2009 decreased by 4.3 per cent (INSTAT, 2010). The sectors most affected by the crisis, especially in 2009, were in industry, and especially buyers of imported raw materials for shoes and clothing. If we compare 2009 with 2008 the highest growth increase in terms of volume could be observed in the services sector ( +5.3 per cent), while the agriculture sector, after increasing by 7.3 per cent in 2008, rose by +3.3 per cent in 2009. In 2009, services generated 58 per cent of GDP compared to 23 per cent for industry and 19 per cent for agriculture (INSTAT, 2009). Industry, however, started to recover quickly in 2010 alongside foreign businesses' growing demand for goods produced in Albania.

The decrease in the quantity of remittances from abroad (remittances from migrants, total 1 billion euros per year) was another sign of the impact of the crisis on the Albanian economy. The impact of the crisis on many European countries, especially Italy and Greece, has had an adverse effect on this important source of revenue for Albanians. The Bank of Albania warned the Albanian government about the decrease in remittances following the effects of the global crises on neighbor countries, where most Albanian emigrants reside. The poor economic outlook is deepening the financial difficulties of entrepreneurs and households, and the Bank of Albania has warned the Government that "the business difficulties will have a negative impact on employment, adversely affecting the incomes of individuals and households" (Bank of Albania, 2008). Clearly, ordinary Albanians, specialized institutions and independent experts similarly started to be worried about their country's economic situation and advised the Government to do something about it. The Albanian Government began to take measures in 2009, including administrative and operational expenditure cuts. Despite wage increases in 2008 and 2009, the wage share as part of budgetary spending declined to 16 and 13 per cent, respectively, in those years compared to 17.1 per cent in 2007 (BOA, 2011). It seems that the reason for the decrease was mainly the reduction in the number of public employees. With regard to wages, constraints were imposed by the IMF as part of the Three-Year Arrangement under the Poverty Reduction and Growth Facility which warned the Albanian Government about wage increases. (IMF, 2008). In other words, the IMF requested a wage freeze in 2009. However, 2009 was an election year so that the Government could not resist increasing both wages and pensions. The IMF also advised the Albanian Government to further tighten wage increases to prevent price increases. However, IMF predictions of zero GDP growth in 2009 were not realized. In fact, GDP rose by 3.3 per cent and official data for the coming period show that the Albanian economy is recovering quickly. In 2010, the Government has also announced increases in wages, pensions and social assistance, despite IMF warnings of another difficult year.

Despite the progress that has been made over the years, from the resulting comparative data that wages in Albania remain relatively low compared with other countries in Eastern Europe. The low level of wages reflects the low level of labor productivity.

\section{Conclusion}

The Albanian economy took advantages of macroeconomic stimulus in the form of fiscal expansion ahead of monetary adjustments, during the financial and global crisis. Raising budget deficit and public debt reflected both the action of automatic stabilizers in the form of reduced income and the countercyclical fiscal policy through wages and capital expenditure increases and also the cost of fiscal burden as a result of government decision to stimulate the economy, while fiscal incentives were narrowing. Although fiscal policy is oriented to raise wages in the public sector, cuts in 
personal expenditure are mainly due to reducing the number of employees in the public sector through increasing efficiency and privatization process and lowering of social contribution expenditure. The governments should improve the capacity of public employment services through increases in financial and technical resources.

A key challenge for Albania as a developing economy is the development of well-designed social protection systems. These will allow workers and their families to reconnecting wages and productivity, to invest in the education of their children, to reduce the amounts of precautionary savings and to develop middle-class consumption patterns. The ILO has shown that effective social protection floors are not beyond what countries can afford, whatever their level of economic development (ILO, 2010e). This shows again the close relationship between tax and wage reforms. It also highlights the need to complement wages, especially when they are so low, by additional sources of well-being.

In general, the economic situation in the region has led to less generous wage increases in all sectors. The performance of wages, however, was not uniform across the sectors. Lower nominal wage increases have been somewhat offset by the slowing down of inflation so that the fall in real wages has so far been less severe than might have been the case if they had been accompanied by high price increases. The evidence presented here confirms the decline in the real wage growth during the crisis. This certainly had an impact on both workers' purchasing power and their consumption and may have contributed to limit or delay the chances of economic recovery.

A wage subsidy per worker per month must be provided in the sectors in crisis, such as textiles, leather and footwear, on condition that wages and social security contributions must be paid in full by the recipients. This condition is important to preserve formal employment. Due to low levels of enforcement and the predominance of the informal economy, the priority for policymakers should not only be on reforming regulations but also on increasing both flexibility and security through other means. In particular, security through more effective and inclusive active and passive labor market policies should be improved in Albania, as a developing country and in the vast majority of the developing countries regardless of changes to labor regulations. It is important to structure the policy and institutional changes to ensure that the goals of improved flexibility and security can be achieved in the context of fiscal and institutional constraints.

Given the weak level of social dialogue, the capacity of social partners should be enhanced to ensure that the trail to flexibility and security is a negotiated solution to the employment and far-reaching development challenges facing the country. The need to stimulate social dialogue to promote mutual solutions to concrete problems through collective bargaining is evident. This may help to ensure a more comprehensive negotiating agenda and provide adequate protection for vulnerable and unorganized groups.

Another need is the linking of wages more closely to productivity and competitiveness. The current reforms have led to important changes in the allocation of labor, notably from the public to the private sector and from larger to smaller enterprises. However, labor supplying remains a dominant feature of the country and major changes in the allocation of labor across industries and regions have yet to occur. Labor markets policies and institutions should ultimately contribute to creating decent jobs and poverty reduction, and thus be aligned to national development plans and poverty reduction strategies.

The wage growth perspective in our country for the coming years, also according to the economic crisis predictions, is optimistic. Workers care about the real wage, not the nominal wage, because the real wage captures the trade-off between leisure time and goods and services. Firms care about the real wage, not the nominal wage, because it measures the true cost of hiring labor. The government must provide grants or concessions with regard to the payment of social security/insurance contributions in order to reduce labor costs and thus stimulate employers' economic activity and preserve employment.

\section{References}

Artis M, Kontelemis and Z, D Osborn, "Classical business cycles for G7 and European countries", CEPR Discussion Paper 1137(1995). Ashenfelter Orley, Comparing real wage rates, Working Paper 570(2012)

Bank of Albania," Statistical Report of the Bank of Albania", (2008).

Bank of Albania," Statistical Report of the Bank of Albania", (2011).

Bank of Albania," Statistical Report of the Bank of Albania", (2013).

Bank of Albania,"Statistical Report of the Bank of Albania", (2010).

Bender, K. and I.Theodossiou, "The Real Wage-Employment Relationship". Journal of Post- Keynesian Economics, 21(1999): $621-637$.

Bils, M., "Real Wages Over the Business Cycle : Evidence from Panel Data". Journal of Political Economy, 93 (4) (1985) : 666 - 689.

Ceni Ahmet, Menaxhimi i Shperblimit, (EMAL,2013),216 - 224.

Deveraux, P.J., "The Cyclicality of Real Wages Within Employer/Employee Matches", Industrial and Labor Relations Review 54(2001) : 835-850. 
Dunlop, J.T., "The Movement of Real and Money Wage Rates". Economics Journal 48(1938):413-434.

Fields Gary S. and Ravi Kanbur, Minimum wages and poverty with income sharing, Journal of economic inequality, (2007).

Fullani Ardian, Review of the Albanian economy in 2009 and outlook for 2010, BIS Review 25(2010).

ILO, Global wage report 2012/2013, Wages and equitable growth,(ILO, 2013).

ILO 2010a. Decent work for domestic workers. Report IV(1), International Labor Conference, 99th Session, p. 7,Geneva, (2010).

ILO 2010e. Working Conditions Laws Report 2010. ILO Conditions of Work and Employment Program. Geneva.

ILO 2012b. Global estimate of forced labor: Results and methodology. Geneva.

IMF, Making the economy work for all, (Global annual report, 2008)

Institute of Statistics, Albania in Figures 2005, (INSTAT, 2005).

Institute of Statistics, Albania in Figures 2010, (INSTAT, 2010).

Institute of Statistics, Albania in Figures 2012, (INSTAT, 2013).

Keynes John. M., The General Theory of Employment, Interest, and Money, (Macmillan London,1936),10.

Kulikov, G. and V. Blyzniuk, "Impact of the financial and economic crisis on wages, income distribution and the tax system", ILO Decent Work Technical Support Team and Country Office for Central and Eastern Europe (2010).

Official Journal of Albania, "Law no. 107/2013, dated 28.03.2013: On some amendments to the law no. 8438, dated 28.12.1998 "On income tax" amended", Gazeta Zyrtare 53(2013).

World Bank,"Shqipëria: Një Vlerësim i Tregut të Punës". World Bank document (2006):4-9.

World Bank (2008). Global financial crisis and implications for developing countries. Washington DC. 